\title{
Distribution and downward flux of Trichodesmium in the South China Sea as influenced by the transport from the Kuroshio Current
}

\author{
Yuh-ling Lee Chen ${ }^{1, *}$, Houng-Yung Chen ${ }^{2}$, Yen-Huei Lin ${ }^{1,2}$ \\ ${ }^{1}$ Department of Marine Resources, and ${ }^{2}$ Institute of Marine Biology, National Sun Yat-sen University, 70 Lien-Hai Rd., \\ Kaohsiung, 804 Taiwan, ROC
}

\begin{abstract}
The South China Sea (SCS) is an oligotrophic marginal sea in the tropical-subtropical western North Pacific. Its warm, stratified and nitrate depleted water is an ideal habitat for the nitrogen- (N) fixing cyanobacteria Trichodesmium. Its abundant presence was not revealed, however, by our results, compiled from 7 cruises conducted between 2000 and 2002 in the northern SCS covering 2 springs (March), 3 summers (June to July) and 2 falls (October). Averaged Trichodesmium density in the surface water was $77 \times 10^{3}$ trichomes $\mathrm{m}^{-3}$ with great spatial and temporal variations. No definite spatial distribution pattern was recognizable. Its depth- (0 to $60 \mathrm{~m})$ integrated abundance was much lower in the springs (57 to $1360 \times 10^{3}$ trichomes $\mathrm{m}^{-2}$ ) than either in the summers (480 to $19229 \times 10^{3}$ trichomes $\mathrm{m}^{-2}$ ) or falls $\left(667\right.$ to $21308 \times 10^{3}$ trichomes $\left.\mathrm{m}^{-2}\right)$. This might be attributed to the relatively shallower nitracline and lower water temperature in the spring than the warm seasons. The year-round abundance was positively related to $(p<0.05)$ both nitracline depth and surface water temperature. In the warm seasons when the surface temperature ranged between 27.1 and $31.3^{\circ} \mathrm{C}$, only the nitracline depth was significantly related to the Trichodesmium abundance. Nitracline depth that was greater in the Kuroshio water compared to the SCS water also plays a decisive role in controlling the Trichodesmium abundance in the 2 regions, being greater in the Kuroshio than in the SCS. A sediment trap system deployed near the Luzon Strait in the SCS collected Trichodesmium samples as deep as $374 \mathrm{~m}$. It showed a maximum downward flux of Trichodesmium at $24.69 \times 10^{3}$ trichomes $\mathrm{m}^{-2} \mathrm{~d}^{-1}$ in September and decreased to $<1 \times 10^{3}$ trichomes $\mathrm{m}^{-2} \mathrm{~d}^{-1}$ from December to March. The sinking rate, when expressed as percentage of the integrated abundance, was 0.1 to 0.3 and $0.05 \%$ for the warm and the cold seasons, respectively. Despite its surface dwelling nature, Trichodesmium showed a downward flux when it was transported from the Kuroshio to the SCS where it became dissipated.
\end{abstract}

KEY WORDS: Trichodesmium $\cdot$ South China Sea $\cdot$ Kuroshio $\cdot$ Temperature $\cdot$ Nitracline $\cdot$ Sediment trap $\cdot$ Downward flux

Resale or republication not permitted without written consent of the publisher

\section{INTRODUCTION}

Nitrogen (N) is considered the most common element limiting phytoplankton growth in the sea (Vitousek \& Howarth 1991). In the tropical or subtropical oceans where $\mathrm{N}$ supply is limited, the non-heterocystous N-fixing cyanobacteria Trichodesmium spp., however, often bloom when waters are warm, calm and stratified
(Carpenter \& Price 1977, Capone et al. 1998). Trichodesmium and other N-fixers may provide large inputs of 'new N' into the systems through fixing $\mathrm{N}$ from the atmosphere (Dugdale et al. 1964, Capone et al. 1997, Karl et al. 1997), and thus contribute significantly to oceanic productivity and the carbon cycle. Of all the N-fixers, Trichodesmium may be the most important contributor to global ocean N-fixation (Capone et al. 1997). 
The South China Sea (SCS) is the largest marginal sea on earth. It is located in the tropical-subtropical western North Pacific and has a surface area of about $3.5 \times 10^{6}$ $\mathrm{km}^{2}$, extending from the equator to $22^{\circ} \mathrm{N}$ (Fig. 1). A deep basin, isolated by broad shelves shallower than $100 \mathrm{~m}$, is located in the northwestern SCS (Fang et al. 1998). The basin has a maximum depth of $5000 \mathrm{~m}$ (Shaw \& Chao 1994) and a surface area of about $1.5 \times 10^{6} \mathrm{~km}^{2}$. The Luzon Strait located between Taiwan and the Philippines is the principal deep channel allowing water exchange between the SCS and the Western Pacific Ocean. Other channels in the Philippine archipelagoes are either too shallow or too narrow for effective water transport. Through the Luzon Strait, the Kuroshio intrudes from the Western Philippine Sea (WPS) into the northern SCS and sends its top $300 \mathrm{~m}$ water westward along the continental slope south of China (Shaw \& Chao 1994). The SCS subsurface water exchanges with the WPS through a sill depth of about $1900 \mathrm{~m}$. As the WPS water enters the SCS at depths between 1500 and 1900 m, its deeper water mass submerges to the bottom of the SCS basin. Its upper water mass mixes upward and eventually flows out of the basin at intermediate depths of 500 to $1000 \mathrm{~m}$ (Gong et al. 1992). The upwelling brings the nutrientladen water closer to the surface, and the nutricline (the layer at which concentration of nutrients changes rapidly with depth) could be therefore uplifted by as much as $100 \mathrm{~m}$ more in the SCS than in the WPS (Gong et al.

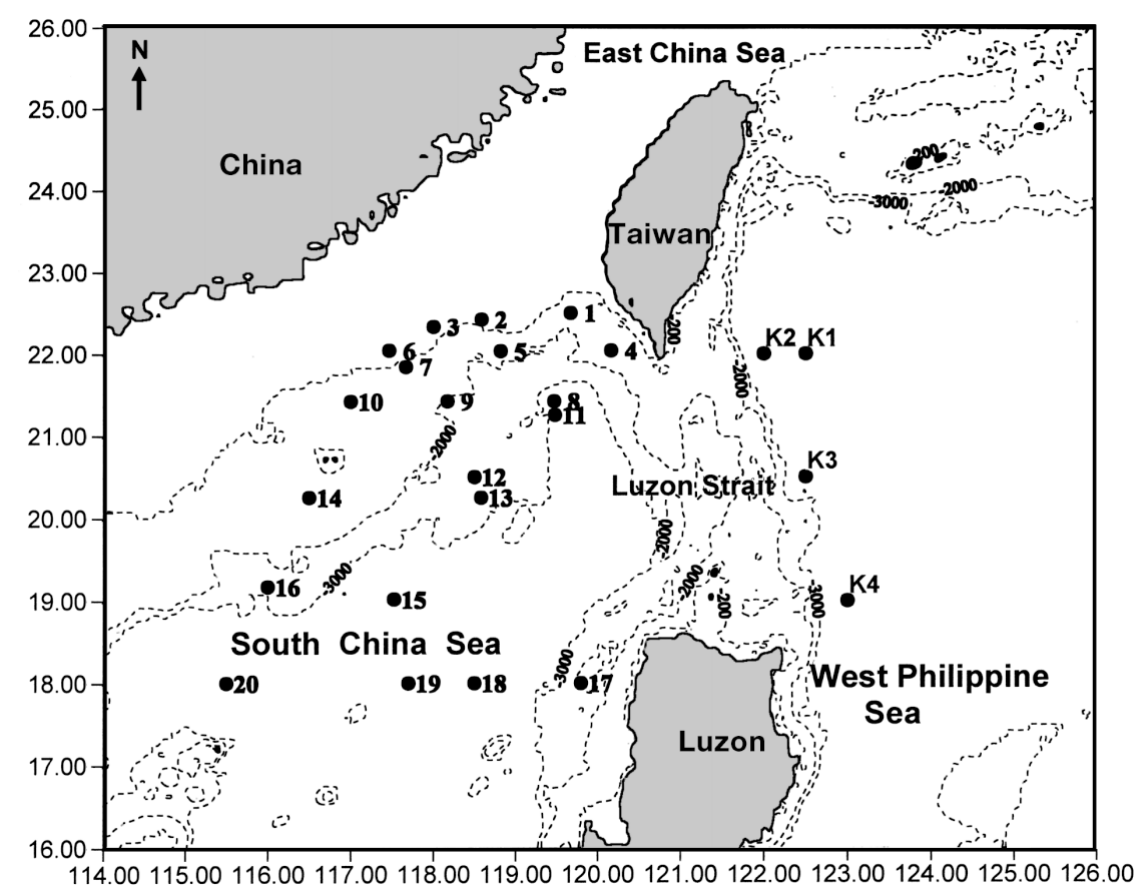

Fig. 1. Bottom topography and locations of the sampling stations on the South China Sea (Stns 1 to 20) and on the Kuroshio Current (Stns K1 to K4) of the West Philippine Sea
1992). The surface circulation of the SCS changes seasonally in response to the prevalent monsoons. The northeastern monsoon, which corresponds to the formation of a cyclonic gyre in the SCS, prevails in winter and spring whereas the southwestern monsoon prevails in summer and autumn when an anti-cyclonic gyre occurs (Liu et al. 2002).

The surface water of the SCS is generally warm, stratified and oligotrophic. Although its N-deficit limits growth of most phytoplankton (Wu et al. 2003), the SCS is supposedly an ideal habitat for N-fixers. Trichodesmium is an indicator species of the Kuroshio water. Its appearance in the Kuroshio and most of its associated waters has been well-documented. However, distribution of Trichodesmium in the vast SCS, which is closely linked with the Kuroshio, has been little known. Although dense patches of Trichodesmium had been encountered in the fall at $5^{\circ} \mathrm{S}$, $110^{\circ} \mathrm{E}$ (Carpenter 1983a) and $10^{\circ} \mathrm{N}, 120^{\circ} \mathrm{E}$ (Saino \& Hattori 1980) and in September at $10^{\circ} \mathrm{N}, 112^{\circ} \mathrm{E}$ (Dareste 1954, in Carpenter 1983a), our understanding of its distribution is far from complete. In the present study, we investigated the seasonal variation of Trichodesmium abundance in the northern SCS and determined the ecological factors controlling its dynamics. We found that Trichodesmium in the SCS was not as abundant as expected. In an effort to understand the effects of the Kuroshio intrusion on the Trichodesmium distribution in the $\mathrm{SCS}$, the results from a summer cruise in the Kuroshio were incorporated into the present study. In addition, the results from the microscopic examinations of the samples from the sediment traps, deployed in the basin of the SCS simultaneously with the cruises, were used to identify the possible fate of Trichodesmium, which is abundant in the Kuroshio (Marumo \& Nagasawa 1976) and dissipates after the Kuroshio intrudes into the SCS. The intrusion, which was previously reported to occur only seasonally from October to February (Shaw \& Chao 1994), is now suggested to be year round (Tang et al. 2002). A maximum intrusion was observed in winter, followed by spring, being weakest in summer ( $\mathrm{Hu}$ et al. 2000). As a Kuroshio water species indicator, Trichodesmium's distribution in the SCS and neighboring Kuroshio as well as its fate after entering the SCS hold the keys to comprehending the biological production, especially the new production of the SCS. 


\section{MATERIALS AND METHODS}

The present study consisted of 3 inter-related components: (1) results of 7 cruise surveys in the northern SCS (Table 1), which described the spatial and temporal distributions of Trichodesmium; (2) results of 1 cruise survey in the Kuroshio of the WPS, which provided a background reference of Trichodesmium abundance in the Kuroshio water; and (3) results of the samples from a sediment trap system deployed near the Luzon Strait at the entrance of the Kuroshio Current intrusion into the SCS, which was used to identify the possible fate of Trichodesmium after being transported into the SCS. Two of the 7 cruises in the SCS (Table 1) were conducted in spring (March 20 to 31, 2001, and March 7 to 15, 2002), 3 in summer (July 3 to 14, 2000, June 27 to July 2, 2001, and July 24 to 27 , 2002) and 2 in fall (October 4 to 13, 2000, and October 22 to 31, 2001). A total of 20 stations (Fig. 1) in the northern SCS were investigated during these cruises. The sampling stations were selected to represent the 3 environments of the northern SCS: the shelf, slope and basin. Their water depths were $<200,200$ to 2000 and $>2000 \mathrm{~m}$, respectively (Table 1). The Kuroshio cruise was conducted during the summer (July 10 to 21) of 2002. It was compared to the results from the cruise conducted in the neighboring SCS in July 24 to 27, 2002 (Table 2).

Water samples for nutrient analyses and Trichodesmium enumeration were collected from 6 to 10 depths in each sampling station using 20 l Go-Flo bottles attached to a rosette multi-sampler, on which the CTD probes were installed (Seabird SBE 9/11). Nitrate and nitrite concentrations were determined by the chemiluminescent method (Garside 1982). Nitracline was defined as the depth at which concentration of nitrate plus nitrite equals $0.1 \mu \mathrm{M}$ (Borgne et al. 2002), and used as the index of nitrate availability to the upperwater phytoplankton. It represents not only surface nitrate stock concentration but also thermocline depth that links to the potential upward diffusion of nitrate. Soluble reactive phosphorus (SRP) concentration was determined at nanomolar level by the modified MAGIC method (Thomson-Bulldis \& Karl 1998) with the arsenate interference being corrected.

Specimens for enumeration of Trichodesmium were prepared on board by filtering 11 sample water on a $10 \mu \mathrm{m}$ Nuclepore filter ( $25 \mathrm{~mm}$ in diameter). A drop of immersion oil was laid on the filter paper that was placed on a microscope slide. A cover slip was then placed on top of the filter. The specimens were kept at $-20^{\circ} \mathrm{C}$ and in darkness until microscopic examination. Trichomes and colonies were counted (Carpenter et al. 1999) at a magnification of 100 to $400 \times$ using a Zeiss epifluorescence microscope with green excitation
Table 1. Sampling time and locations of sampling stations investigated in 7 cruises in the South China Sea. Sampling stations were grouped as the shelf $(<200 \mathrm{~m})$, slope (between 200 and $2000 \mathrm{~m})$ or basin $(>2000 \mathrm{~m})$ stations by bottom depth. Numbers designate sampling stations

\begin{tabular}{|lcccc|}
\hline \multirow{2}{*}{ Season } & Sampling & \multicolumn{3}{c|}{ Stn } \\
\cline { 3 - 5 } & time & Shelf & Slope & Basin \\
\hline Spring & Mar 2001 & 2,3 & $1,10,14$ & $13,16,17,19,20$ \\
& Mar 2002 & 2,3 & 10,14 & $8,13,15,19,20$ \\
Summer & Jul 2000 & & 1,9 & 20 \\
& Jun-Jul 2001 & 2,3 & 1,10 & 13 \\
\multirow{4}{*}{ Fall } & Jul 2002 & & & $12,17,18$ \\
& Oct 2000 & 6 & $4,5,7$ & $11,13,15,20$ \\
& Oct 2001 & & 14 & $13,17,19,20$ \\
\hline
\end{tabular}

(BP 510-560, FT 580, LP 590). Depth integrated Trichodesmium abundance was calculated by trapezoidal integration from the surface to $60 \mathrm{~m}$ depth and expressed as trichomes $\mathrm{m}^{-2}$ since most of Trichodesmium was found in the top $60 \mathrm{~m}$ water column.

A time-series sediment trap system was used to collect settling particles at 4 different depths (374, 925, 1925 and $2702 \mathrm{~m}$ ) at Stn 8 in the SCS basin (Fig. 1), which had a bottom depth of $2943 \mathrm{~m}$. Stn 8 was located near the Luzon Strait, where the Kuroshio Current enters the SCS. The trap was coned-shaped with 12 revolving cup collectors and each had a collection area of $0.125 \mathrm{~m}^{2}$. The trap system was deployed from September 22, 2001, to March 20, 2002. Each sample represented the cumulative sediment of a $15 \mathrm{~d}$ period. The samples were preserved with neutralized formalin in the collecting cups. For partitioning, the sample in the collecting cup was thoroughly mixed before three $1 \mathrm{ml}$ aliquots were withdrawn from the top, middle and bottom of the collecting cup, respectively. The 3 aliquots were then mixed and transferred to an Utermöhl counting chamber and left to settle for $24 \mathrm{~h}$

Table 2. Trichodesmium spp. Top $60 \mathrm{~m}$ depth-integrated abundance $\left(\times 10^{3}\right.$ trichomes $\left.\mathrm{m}^{-2}\right)$ of Trichodesmium that were collected in 2 cruises conducted in 2002, in the South China Sea

(July 24 to 27) and the Kuroshio Current (July 10 to 21)

\begin{tabular}{|lc|}
\hline Stn & Abundance $\left(\times 10^{3}\right.$ trichomes $\left.\mathrm{m}^{-2}\right)$ \\
\hline South China Sea & \\
12 & 8244 \\
17 & 561 \\
18 & 3084 \\
Kuroshio Current & \\
K1 & 19502 \\
K2 & 44247 \\
K3 & 43147 \\
K4 & 12880 \\
\hline
\end{tabular}


before being enumerated under an inverse microscope (Zeiss Axioskop).

The simple linear regression analyses between depth-integrated abundance of Trichodesmium and surface temperature, depth-integrated abundance of Trichodesmium and nitracline depth, and nitracline depth and nitrate+nitrite concentration were performed using StatView software (SAS Institute). A step-wise multiple regression analysis procedure (Draper \& Smith 1981) was used to examine the relationships between the depth-integrated abundance of Trichodesmium and the surface water temperature, salinity, nitrate+nitrite concentration, SRP and depth of nitracline.

\section{RESULTS AND DISCUSSION}

\section{Distributions of Trichodesmium in the SCS}

The SCS was warm, stratified and oligotrophic during the sampling periods. Surface water temperature ranged between 22.3 and $31.3^{\circ} \mathrm{C}$. Surface nitrate concentration as low as $5 \mathrm{nM}$ was detected in a summer sample. In general, surface nitrate concentration was higher in the springs (seasonally averaged concentration, $166 \mathrm{nM}$ ) than that in the summers (averaged concentration, $21 \mathrm{nM}$; excluding some extreme values) and in the falls (averaged concentration, $26 \mathrm{nM}$ ). Surface SRP concentrations were relatively high, resulting in very low [NO3+NO2]/SRP ranging between 0.2 and 7.7. Averaged SRP concentration was 58, 19 and $18 \mathrm{nM}$ in the springs, summers and falls, respectively. Previous nutrient enrichment experiments in the SCS had confirmed that phytoplankton growth is constrained by $\mathrm{N}$-deficiency (Wu et al. 2003). In the enrichment experiments, only when nitrate was added, phytoplankton growth was stimulated and chlorophyll a (chl a) concentration significantly increased. Mixed layer depth was generally 30 to $50 \mathrm{~m}$ (Fig. 2). The results of a representative station at the basin, Stn 13, is presented in Fig. 2 to illustrate the typical oligotrophic and stratified patterns of the water column in the SCS and the seasonal variations of nutrient concentrations and Trichodesmium densities.

Trichodesmium was not abundantly distributed in the northern SCS. Its averaged density was $77 \times 10^{3}$ trichomes $\mathrm{m}^{-3}$ in the surface water, with a maximum and minimum density of 0 and $962 \times 10^{3}$ trichomes $\mathrm{m}^{-3}$, respectively. The maximum density in the SCS was higher than that in the East China Sea $\left(600 \times 10^{3}\right.$ trichomes $\mathrm{m}^{-3}$, Chang et al. 2000). Both maximums are small when compared to the densities of Trichodesmium blooms $\left(17 \times 10^{6}\right.$ trichomes $\mathrm{m}^{-3}$ ) reported in the central Arabian Sea (Capone et al. 1998) or off the coast of India $\left(39 \times 10^{9}\right.$ trichomes $\mathrm{m}^{-3}$, Devassy et al. 1978). Vertically, Trichodesmium distributed mainly in the top $60 \mathrm{~m}$ (Fig. $3)$, with a maximum at $10 \mathrm{~m}$ depth or $46 \%$ light depth. This vertical distribution is comparable to those described for other oceans, which are typically $15 \mathrm{~m}$ (Carpenter \& Price 1977).

Depth-integrated abundance of Trichodesmium showed great temporal and spatial variations. It was

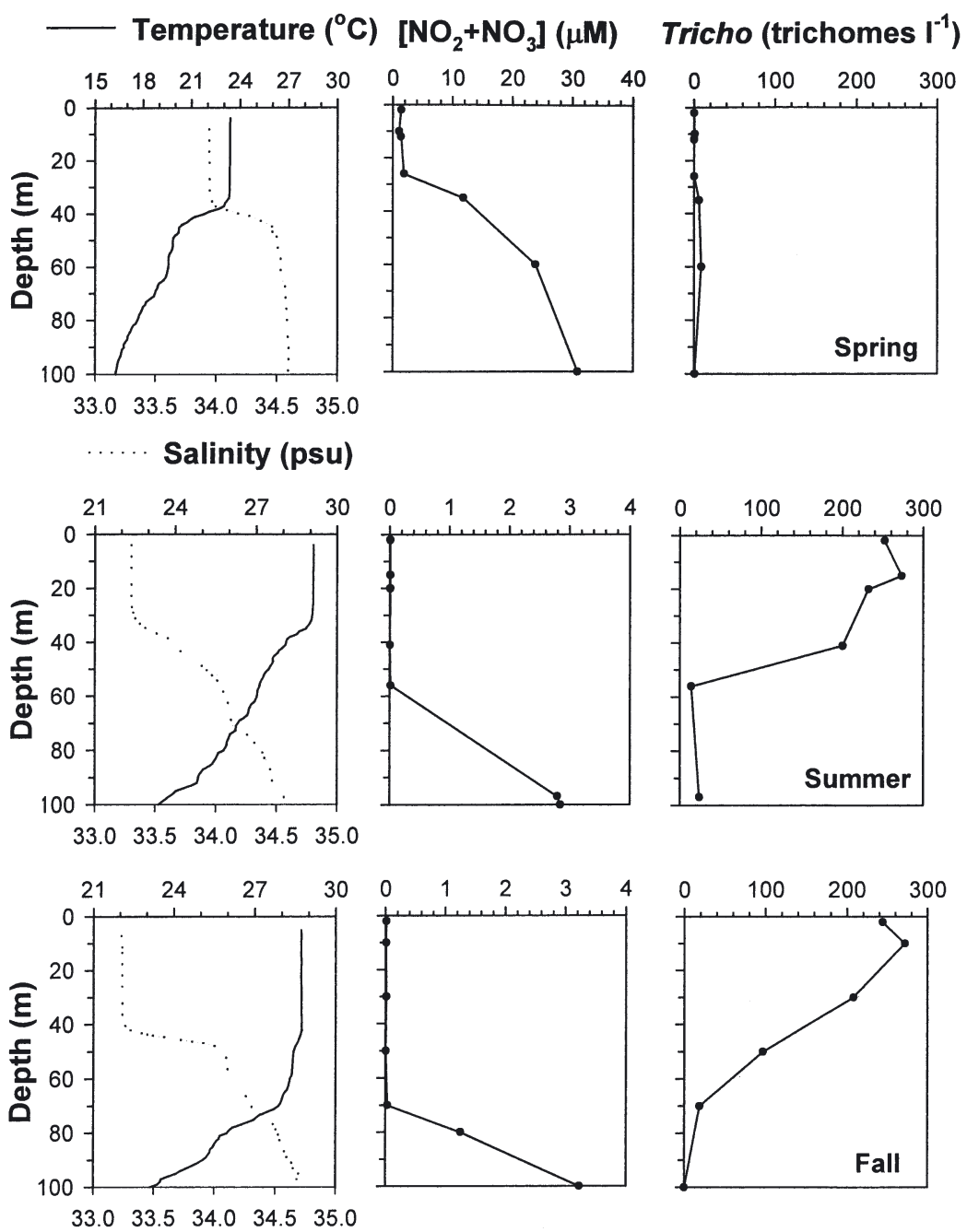

Fig. 2. Trichodesmium spp. Seasonal variations of top $100 \mathrm{~m}$ vertical profiles of surface temperature, salinity, $\left[\mathrm{NO}_{3}+\mathrm{NO}_{2}\right]$ and Trichodesmium density in Stn 13 located at the deep basin of the South China Sea 


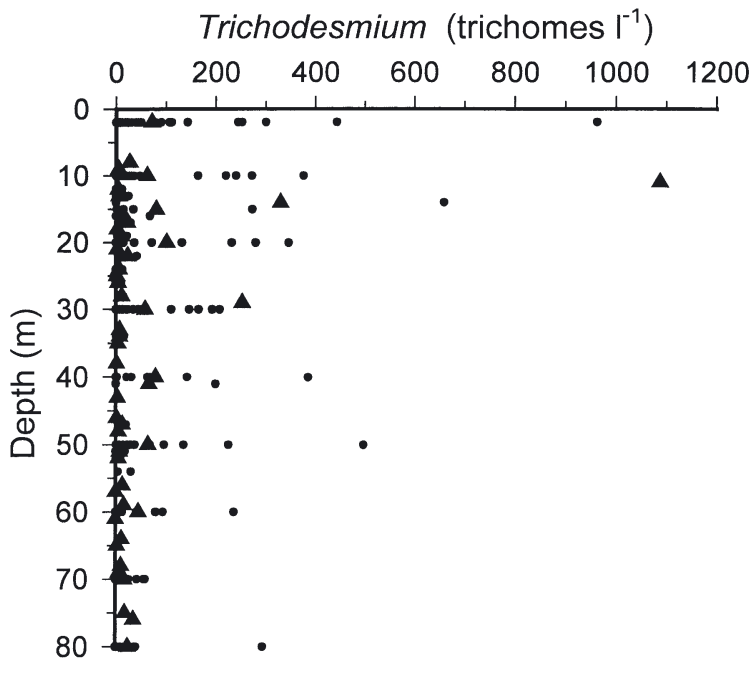

Fig. 3. Trichodesmium spp. Top $80 \mathrm{~m}$ density profile of Trichodesmium in the South China Sea. $\mathbf{\Delta}$ : means of Trichodesmium densities $(\bullet)$ at respective depths for all cruises

very low in the springs with an average of $435 \times 10^{3}$ trichomes $\mathrm{m}^{-2}$ and a range of 57 to $1360 \times 10^{3}$ trichomes $\mathrm{m}^{-2}$. Trichodesmium was apparently more abundant in the summers (average $5267 \times 10^{3}$ trichomes $\mathrm{m}^{-2}$ ) and the falls (average $5345 \times 10^{3}$ trichomes $\mathrm{m}^{-2}$ ). Greater spatial variations were observed in the summers $(480$ to $19229 \times 10^{3}$ trichomes $\mathrm{m}^{-2}$ ) and the falls (667 to $21308 \times 10^{3}$ trichomes $\mathrm{m}^{-2}$ ) than in the springs. No definite spatial distribution pattern was recognizable, except that some patchy dense aggregations were found in the summers at the entrance of the Luzon Strait where Stn 13 was located and in the fall at Stn 19 in the basin.

This distribution of Trichodesmium abundance (TA, trichomes $\mathrm{m}^{-2}$ ) was significantly related to surface water temperature (Fig. 4A) and nitracline depth (Fig. 4B). Multiple regression analysis depicted their relationships as: $\log \mathrm{TA}=-0.908+0.133 T+0.008 \mathrm{Dn}$ $\left(\mathrm{n}=43, \mathrm{R}^{2}=0.53\right)$, where $T$ is surface water temperature and Dn is the nitracline depth.

\section{Factors limiting Trichodesmium distribution in the SCS}

\section{Temperature and nitracline}

Although both surface temperature and nitracline depth are the determinant parameters of Trichodesmium abundance, surface temperature has a far greater influence than nitracline depth does. This assertion was made based on the partial $F$-values of the multiple regression analysis. Partial F-values indicate the significance of respective independent variables (temperature and nitracline depth in the present analysis) to dependent variables (Trichodesmium abundance). The higher the partial Fvalue is, the more significant the independent variable. In the present multiple regression analysis, the partial $F$-value of the surface temperature was higher than that of the nitracline depth. Trichodesmium usually thrives when temperature is $25^{\circ} \mathrm{C}$ or higher. For example, in the Sargasso Sea, it blooms only in summer and fall when surface temperature is above $25^{\circ} \mathrm{C}$ (Dugdale et al. 1961). In the northern SCS, the surface water temperatures during March to October ranged between 22.3 and $31.3^{\circ} \mathrm{C}$ with spatial variations in the summers $\left(28.4\right.$ to $\left.31.3^{\circ} \mathrm{C}\right)$ and the falls $\left(27.1\right.$ to $\left.29.9^{\circ} \mathrm{C}\right)$ being much smaller than those in the springs ( 22.3 to $27.7^{\circ} \mathrm{C}$ ). The low Trichodesmium abundance that was observed constantly in March might be attributed to the low surface water temperature. Mean surface water temperature was $24.7^{\circ} \mathrm{C}$ in the springs, compared to $29.2^{\circ} \mathrm{C}$ in the summers and $28.5^{\circ} \mathrm{C}$ in the
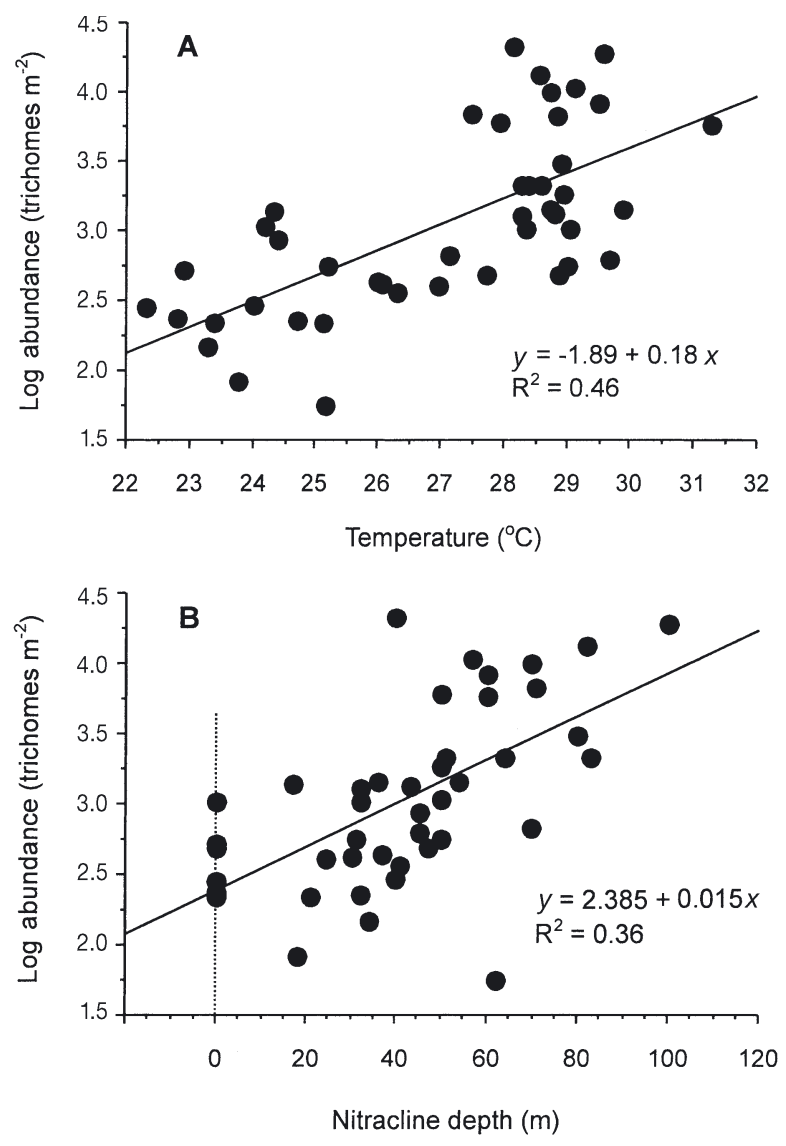

Fig. 4. Trichodesmium spp. Relationship between depth- (0 to $60 \mathrm{~m}$ ) integrated Trichodesmium abundance and (A) surface water temperature as well as (B) depth of the nitracline in the South China Sea. Data were compiled from the results of 7 cruises 
falls. Marumo \& Nagasawa (1976) found that the standing crop of Trichodesmium in the Kuroshio water, being abundant in summer and almost absent in winter, is also well-correlated with the variation of surface water temperature.

The depth of nitracline was positively related to Trichodesmium abundance (Fig. 4B). The lower abundance in the springs than in the warm seasons corresponded well with the increase of the nitracline depth from each spring's low. The nitracline was on average shallower in the springs $(28 \mathrm{~m})$ than in the summers $(50 \mathrm{~m})$ or the falls $(56 \mathrm{~m})$. With the submersion of nitracline and decline of available nutrients in the surface water (Integrated $\left[\mathrm{NO}_{3}+\mathrm{NO}_{2}\right]=159.23-84.98 \log [\mathrm{Dn}]$, $\mathrm{p}<0.05)$, the environment became more favorable for the growth of Trichodesmium than non-N-fixers. Dense populations of Trichodesmium thiebautii in the surface water of the Sargasso Sea were also observed during periods of nutrient impoverishment (Dugdale et al. 1961).
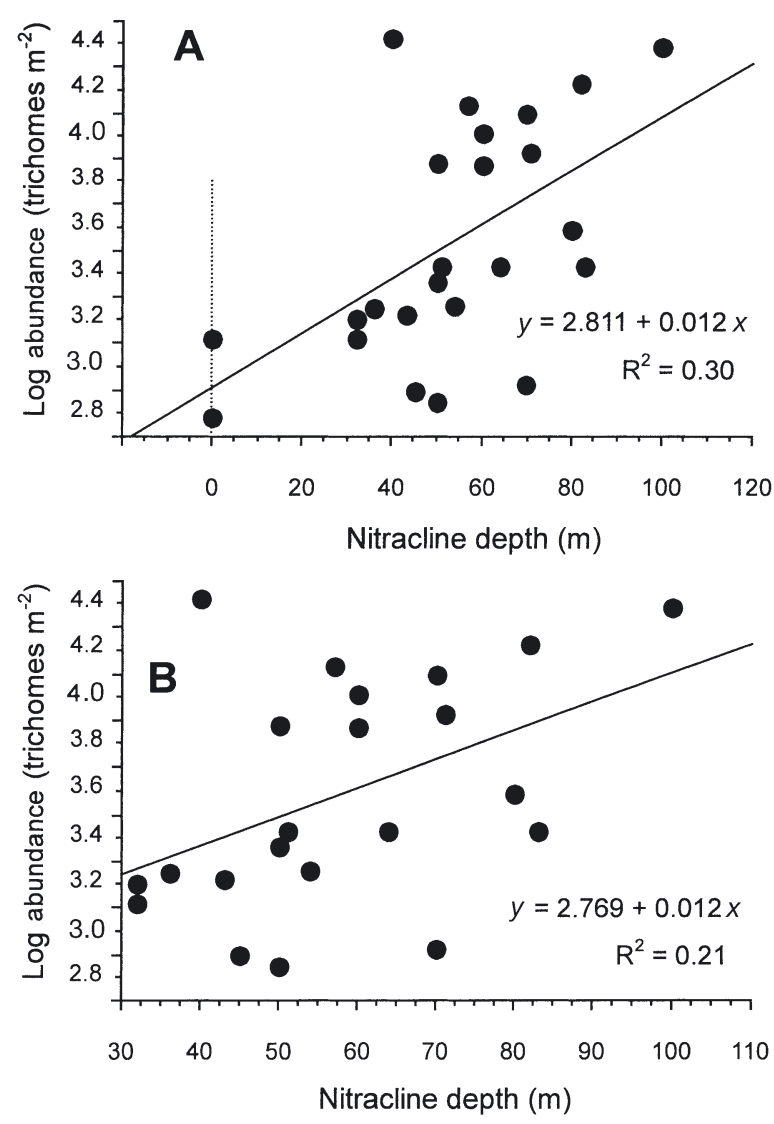

Fig. 5. Trichodesmium spp. Relationship of depth- (0 to $60 \mathrm{~m})$ integrated Trichodesmium abundance and depth of nitracline based on the whole data set observed during warm seasons (summer and fall) in the South China Sea (A); and on the data set with extreme values that showed a nitracline depth of $0 \mathrm{~m}$ being excluded (B)
The nutricline often oscillates with the thermocline. As water temperature increases, the nutricline, such as the nitracline, usually submerges. Surface temperature and nitracline depth therefore tend to confound each other, i.e. as the indicators of nitrate availability, their effects are not separable. The use of multiple regression analysis, however, separated the confounding of these 2 factors. Both partial regression coefficients of surface temperature and nitracline depth in the multiple regression analysis were significant, and so were their regression coefficients in simple linear regression analysis, as shown on Fig. 4. Therefore, it was not just the high temperature and the low nutrient availability that resulted in increased Trichodesmium density, temperature itself or other factors that fluctuated concurrently with water temperature could have played influential roles in limiting the abundance of Trichodesmium. Possible candidates of these other factors include light intensity, dust input, Kuroshio intrusion, stability of water column, etc.

In an attempt to decipher the factors that really control the spatial variation of Trichodesmium during the warm seasons, we excluded the spring data set from the statistical analysis, because these data tended to show lower water temperature and shallower nitracline than the summer and fall sets. In this analysis, nitracline depth was still significantly related to Trichodesmium abundance (Fig. 5A), but not surface water temperature $(\mathrm{p}>0.05)$, which ranged between 27.1 and $31.3^{\circ} \mathrm{C}$. This result reconfirmed that the surface water temperature played little or no role in limiting Trichodesmium growth when it was above $25^{\circ} \mathrm{C}$. In the readjusted data sets, there were still extreme values from 2 sampling stations studied in the summers. The 2 stations showed at the same nitracline depth of $0 \mathrm{~m}$, surface nitrate concentrations of up to 3.01 and $1.31 \mu \mathrm{M}$ and salinities of 29.90 and $30.87 \mathrm{psu}$, respectively. These extreme values could bias the linear relationship between Trichodesmium abundance and nitracline depth (Fig. 5A). In the third analysis in which the 2 data points were excluded, similar statistical relations were shown (Fig. 5B).

The low abundance of Trichodesmium in shallowly nitraclined waters does not necessary mean that the growth of Trichodesmium was suppressed or hurt by high nitrate concentration. In laboratory studies, Trichodesmium spp. can utilize low levels (Carpenter \& McCarthy 1975) or sometimes high levels (Saino \& Hattori 1978) of nitrogenous compounds such as $\mathrm{NO}_{3}{ }^{-}$, $\mathrm{NH}_{4}{ }^{+}$and organic $\mathrm{N}$ in culture mediums. Ohki et al. (1986) indicated that the growth of $T$. thiebautii and T. erythraeum was not affected by nitrate supplement even after 10 transfers of the algal cultures. Nitrate supplement showed no apparent adverse effect on Trichodesmium growth despite the nitrate uptake 
capacities of Trichodesmium being varied. On the other hand, successions of diatoms and Trichodesmium were observed to take turns in dominating the phytoplankton community in the Great Barrier Reef Lagoon (Bell et al. 1999); when nitrate was abundant, diatoms became dominant. The fast growing diatoms out competes the slow growing Trichodesmium (Mulholland \& Capone 2000) in nitrate-rich waters. This could be attributed partially to the high water turbulence that also results in eutrophication. Water turbulence, therefore, is a factor that cannot be ruled out when treating the relationships between Trichodesmium abundance and nitracline.

\section{Iron deficiency}

A potential impact from the atmospheric input of iron (an important element for the $\mathrm{N}$-fixing enzyme nitrogenase, Falkowski 1997) on N-fixation has been proposed for some time (Rueter et al. 1990, 1992). $\mathrm{N}$-fixation in tropical and subtropical seas is limited by the availability of iron and also by the deficit of phosphorus (Sanudo-Wilhelmy et al. 2001). In the SCS, phosphorus is unlikely to be deficient. Iron deficiency, on the other hand, appears likely. Wu et al. (2003) suggested that in the SCS, Trichodesmium biomass is restrained by limited dissolved iron availability in spite of a high aeolian iron flux in the system (Gao et al. 2001). The suggestion made by Wu et al. (2003) was based on the observations at 1 station (Stn 20 in the present study) in the SCS. In that snapshot observation, the authors found that dissolved iron concentration was very low $(0.2$ to $0.3 \mathrm{nM})$ and Trichodesmium were scarcely distributed. In the present study, Trichodesmium biomass at Stn 20 was also low (5 to $48 \times 10^{3}$ trichomes $\mathrm{m}^{-3}$ in surface water). However, there were great temporal and spatial variations of Trichodesmium abundance in the SCS, with the highest surface density $\left(962 \times 10^{3}\right.$ trichomes $\left.\mathrm{m}^{-3}\right)$ being 20 to 180 times the density of Stn 20. Although the present results indicated that the temporal and spatial variations of Trichodesmium biomass were mainly related to surface water temperature and nitracline depth, the possible role of dissolved iron still cannot be ruled out.

Besides Trichodesmium, the significance of other $\mathrm{N}$-fixing organisms, such as unicellular cyanobacterium (Zehr et al. 2001), is yet to be determined in the SCS. Our preliminary study on another well-known filamentous heterocyst-forming N-fixer Richelia intracellularis, which is a symbiont of diatoms, also revealed a relatively low standing crop, with an averaged surface density of $16 \times 10^{3}$ trichomes $\mathrm{m}^{-3}$ (authors' unpubl. data).

\section{Comparisons of Trichodesmium distributions in the SCS and the Kuroshio}

The Kuroshio waters showed a much higher Trichodesmium abundance than the SCS (Table 2). During the Kuroshio cruise (July 10 to 21, 2002), 4 stations (Stns K1 to K4, Fig. 1) on the WPS were studied, and 3 stations (Stns 12, 17 and 18, Fig. 1) were studied, during the SCS cruise (July 24 to 27,2002 ). These 2 arrays of sampling stations were generally scattered at comparable latitudes, except that they were separated by the Luzon Strait and its islands. The temperature versus salinity (T-S) diagrams of the 4 Kuroshio stations (Fig. 6) clearly showed the distinctive salinity characteristics of the Kuroshio water, being higher in maximum but lower in minimum than the respective salinity extreme of the SCS waters (Chen \& Huang 1996). The Kuroshio water with the maximum salinity is higher in both temperature (about $21^{\circ} \mathrm{C}$ ) and salinity (34.9 psu) than those of the SCS waters; similarly, the Kuroshio water with the minimum salinity is lower in temperature (about $7^{\circ} \mathrm{C}$ ) and salinity (34.2 psu) than those of the SCS waters (Chen \& Huang 1996). Mean surface water temperature of all Kuroshio stations $\left(29.7^{\circ} \mathrm{C}\right)$ was similar to that of all SCS stations $\left(29.1^{\circ} \mathrm{C}\right)$; however, mean surface salinity (Fig. 7) was higher in the Kuroshio (34.2 psu) than in the SCS (33.3 psu). Nitrate was depleted in surface water in both regions. Surface nitrate concentration ranged from 5 to $46 \mathrm{nM}$ in the Kuroshio and 5 to $10 \mathrm{nM}$ in the SCS, whereas SRP concentration was 15 to $32 \mathrm{nM}$ and 14 to $18 \mathrm{nM}$, respectively. All ratios of $\left[\mathrm{NO}_{3}+\mathrm{NO}_{2}\right] / \mathrm{SRP}$ were lower

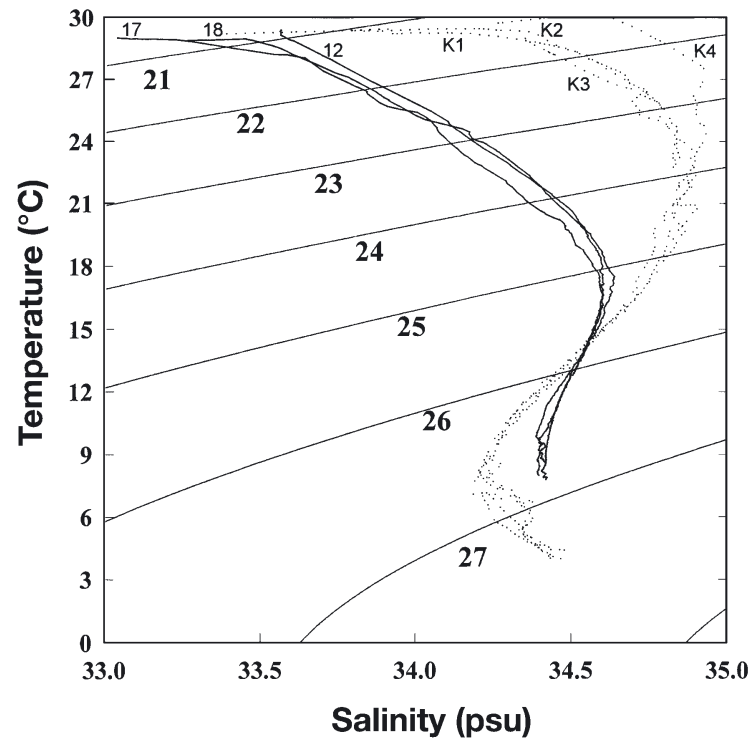

Fig. 6. Temperature versus salinity (T-S) diagrams of the Kuroshio Current (broken lines, Stns K1 to K4) and the South China Sea (solid lines, Stns 12, 17 and 18) 
Tricho (trichomes $\mathrm{I}^{-1}$ )
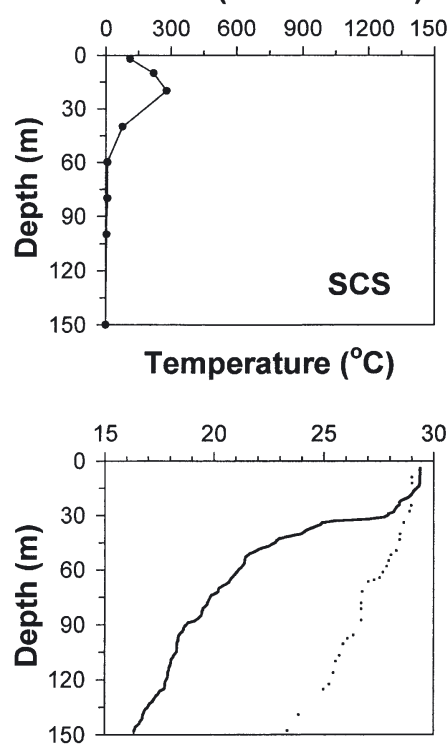

$\left[\mathrm{NO}_{2}+\mathrm{NO}_{3}\right](\mu \mathrm{M})$
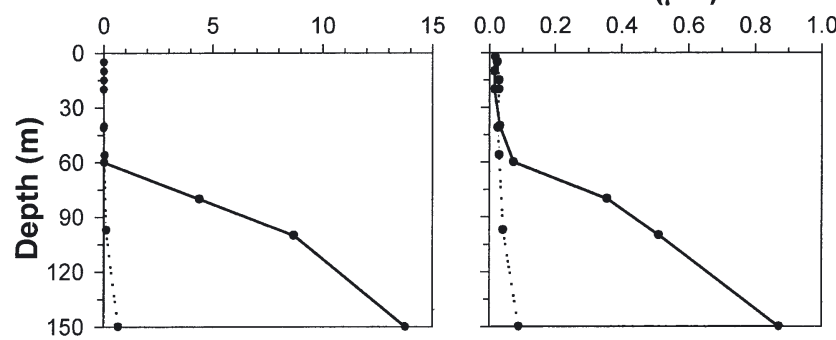

Fig. 7. Trichodesmium spp. Top $150 \mathrm{~m}$ vertical profiles of Trichodesmium density, water temperature, salinity, $\left[\mathrm{NO}_{3}+\mathrm{NO}_{2}\right]$, [soluble reactive phosphorus] of Stn K4 located in the Kuroshio (broken lines) and Stn 12 in the South China Sea (solid lines)

than the Redfield Ratio of 16, indicating the state of $\mathrm{N}$-deficiency. In contrast, the nitracline was found much shallower in the SCS (54 m) than in the Kuroshio $(92 \mathrm{~m})$. This again supported the assertion that Trichodesmium biomass in these oligotrophic seas was much controlled by nitracline depth. Physiochemical and biological qualities of 2 stations typical of the Kuroshio (Stn K3) and the SCS (Stn 12) are compared in Fig. 7.

The status of $\mathrm{N}$-deficiency could be altered when dissolved organic $\mathrm{N}$ (DON) was included in the N-budget. Phytoplankton can use a fraction of DON (Bronk 2002). This is especially important in the tropical-subtropical environment such as the SCS where inorganic nutrients are scarce in the euphotic zone (Jackson \& Williams 1985, Vidal et al. 1999). However, DON concentration in the surface water of the SCS (6 to $9.9 \mu \mathrm{M}$, Liu 2001) is in general as high as in the Kuroshio water (6 to $7 \mu \mathrm{M}$, Hung et al. 2003). If its bioavailability to phytoplankton growth is comparable between the 2 regions, the possibility that DON plays a role in restraining Trichodesmium population in the SCS is slim.

$\mathrm{N}$-fixation costs a lot of energy. Light limitation, however, could not be linked to the spatial difference of Trichodesmium abundance between the SCS and the Kuroshio. Since the SCS and the Kuroshio are located at approximately the same latitude, surface irradiance intensities are generally similar. Water column light extinction coefficients (Ks) were 0.03 to $0.05 \mathrm{~m}^{-1}$ in the Kuroshio (Stns K2, K3 and K4) and 0.04 to $0.05 \mathrm{~m}^{-1}$ in the SCS (Stns 12,17 and 18). In both the SCS and the Kuroshio, Trichodesmium distributed mainly between 0 and $60 \mathrm{~m}$, a depth shallower than its euphotic depth of $92 \mathrm{~m}$. It is thus unlikely that the low Trichodesmium abundance in the SCS was caused by light limitation.

\section{Downward flux of Trichodesmium}

Although aggregated at the upper water layer (Fig. 7), trichomes of Trichodesmium were found in the sediment trap samples collected at as deep as $374 \mathrm{~m}$, and on one occasion at $925 \mathrm{~m}$, when the highest abundance was observed in the $374 \mathrm{~m}$ samples (Table 3). Trichodesmium has been collected from as deep as 150 to $240 \mathrm{~m}$ in the North Pacific (Marumo \& Asaoka 1974). It controls its vertical position in the water column through synthesis or consumption of carbohydrate ballast in the cells. This mechanism can regulate the colonies to sink to as deep as 100 to $200 \mathrm{~m}$ (Kromkamp \& Walsby 1992). Due to this sinking, Trichodesmium was hypothesized to uptake phosphorus from below the nutricline (Letelier \& Karl 1998). However, such a

Table 3. Trichodesmium spp. Daily downward flux of Trichodesmium $\left(\times 10^{3}\right.$ trichomes $\left.\mathrm{m}^{-2} \mathrm{~d}^{-1}\right)$ that was calculated from the density of the samples collected from 374,925, 1925 and $2702 \mathrm{~m}$ depths in the 12 revolving collecting cups of a sediment trap system deployed at the South China Sea between September 22, 2001, and March 20, 2002

\begin{tabular}{|llrccc|}
\hline \multirow{2}{*}{$\begin{array}{l}\text { Cup } \\
\text { no. }\end{array}$} & Collection time & \multicolumn{5}{c|}{ Collection depth (m) } \\
& period & 374 & 925 & 1925 & 2702 \\
\hline 1 & Sep 22-Oct 06, 2001 & 24.69 & 0.05 & 0 & 0 \\
2 & Oct 07-21, 2001 & 5.14 & 0 & 0 & 0 \\
3 & Oct 22-Nov 05, 2001 & 6.36 & 0 & 0 & 0 \\
4 & Nov 06-20, 2001 & 4.56 & 0 & 0 & 0 \\
5 & Nov 21-Dec 05, 2001 & 1.26 & 0 & 0 & 0 \\
6 & Dec 06-20, 2001 & 0.14 & 0 & 0 & 0 \\
7 & Dec 21, 2001-Jan 04, 2002 & 0.23 & 0 & 0 & 0 \\
8 & Jan 05-19, 2002 & 0.19 & 0 & 0 & 0 \\
9 & Jan 20-Feb 03, 2002 & 0.05 & 0 & 0 & 0 \\
10 & Feb 04-18, 2002 & 0.28 & 0 & 0 & 0 \\
11 & Feb 19-Mar 05, 2002 & 0.09 & 0 & 0 & 0 \\
12 & Mar 06-20, 2002 & 0.42 & 0 & 0 & 0 \\
& & & & & \\
\hline
\end{tabular}


migratory process would not bring nutrient benefits to the Trichodesmium populations in the SCS because phosphate concentration is already high in the surface water.

Cyanobacteria are seldom regarded as the significant contributors to the downward flux of organic matter from the euphotic zone; thus, most elements incorporated into the Trichodesmium biomass in the euphotic zone are believed to recycle within the same zone (Letelier \& Karl 1998). This assertion is based on the observation that the external pressure needed to collapse the gas vacuoles of Trichodesmium cells is as high as 12 to 37 bar (Walsby 1978). To appreciate the sinking flux of Trichodesmium in the region, the density of Trichodesmium in the trap cups was converted to daily sinking rate $(\mathrm{S})$ by the equation $\mathrm{S}=\mathrm{Sd} \times$ 100/Sp, where Sd (trichomes $\mathrm{m}^{-2} \mathrm{~d}^{-1}$ ) was the downward flux and $\mathrm{Sp}$ (trichomes $\mathrm{m}^{-2}$ ) was the depthintegrated standing crop of Trichodesmium for the top $60 \mathrm{~m}$ of water column. The daily sinking rate in March was $0.05 \%$ when the Sd was $0.42 \times 10^{3}$ trichomes $\mathrm{m}^{-2}$ $\mathrm{d}^{-1}$ (Table 3) and Sp was $866 \times 10^{3}$ trichomes $\mathrm{m}^{-2}$. In the calculation for the September results, because there was no real-time Sp available, the results from the Kuroshio waters (averaged $29.9 \times 10^{6}$ trichomes $\mathrm{m}^{-2}$, Table 2) and from nearby Stn $12\left(8.24 \times 10^{6} \mathrm{~m}^{-2}\right.$, Table 2) were used, assuming that Trichodesmium abundances in the Kuroshio during September and July were similar. When the Sd was $24.69 \times 10^{3}$ trichomes $\mathrm{m}^{-2} \mathrm{~d}^{-1}$ (Table 3 ), the daily sinking rate was 0.1 to $0.3 \%$, which is comparable to the low ranges ( 0.27 to $9.5 \%$ ) reported for other microplanktonic diatom, dinoflagellates and small flagellates in the Antarctic Peninsula water (Anadon et al. 2002). This sinking rate is, however, smaller than the low end of Trichodesmium's daily growth rate (3.5 to $69.0 \%$ ) estimated based on a turnover time of 1 to $20 \mathrm{~d}$ (Carpenter \& Romans 1991). At this daily downward flux, ca. $12 \mathrm{mg} \mathrm{C} \mathrm{m}^{-2}$ or $2.4 \mathrm{mg} \mathrm{N} \mathrm{m}^{-2}$ was transported from the euphotic zone to the dysphotic depths as Trichodesmium sank, assuming that each colony of Trichodesmium contains 220 trichomes, or $11.6 \mu \mathrm{g}$ of carbon and $2.17 \mu \mathrm{g}$ of $\mathrm{N}$ (Carpenter 1983b). The presence of Trichodesmium between 374 and $925 \mathrm{~m}$ in the SCS, indicated its possible involvement in the nutrient recycle in the dysphotic zone. This nutrient flux into the depths of the SCS constitutes a nutrient source, which could be transported to waters as remote as the East China Sea. It is known that after the WPS water enters the SCS at depths between 1500 and $1900 \mathrm{~m}$, its upper layer mixes upward and eventually flows out of the SCS basin at intermediate depths of 500 to $1000 \mathrm{~m}$ (Gong et al. 1992). It then rejoins the Kuroshio Current off the eastern coast of Taiwan and flows northward to the East China Sea. The nutrients of the SCS inter- mediate water, to which downward flux of Trichodesmium contributes, is thus considered a nutrient source that could be carried by the Kuroshio to as far as the East China Sea (Chen 1996) and even beyond.

The occurrence of internal solitons is one possible answer that could explain the ample quantities of Trichodesmium present in the sediment trap. The trap was deployed at a site where internal waves are common and through which the Kuroshio intrusion water passes. The internal waves in the SCS are generated in the Luzon Strait and propagate westward (Hsu \& Liu 1999) into the northern SCS. Their wave crest can be as long as $200 \mathrm{~km}$ with amplitudes up to $100 \mathrm{~m}$ (Hsu \& Liu 1999). Trichodesmium that were carried by the Kuroshio Current on route to the SCS could easily be dissipated to the dysphotic depth by the internal solitons after entering the SCS. The abundance of Trichodesmium collected in the trap basically followed the seasonal pattern of Trichodesmium density in the Kuroshio surface water, being abundant in the warm season and scarce in the cold season (Marumo \& Nagasawa 1976). This conformity supports the assertion that the Kuroshio flowed through the trap deployment site. According to Hu et al. (2000), a westward branch of the Kuroshio splits from the main current and flows westward through the Luzon Strait into the SCS at about $21^{\circ} \mathrm{N}$. The location of the sediment trap deployment was right on the described current path of the Kuroshio (Fig. 1). The sedimentation of Trichodesmium through downward flux and the shallow mixed layer in the SCS explain the scarcity of Trichodesmium in the northern SCS where constant intrusion of the Kuroshio into the SCS is observed (Tang et al. 2002). The strength of the intrusion of the Kuroshio into the SCS is reciprocal to the abundance of Trichodesmium in the Kuroshio water, which showed an obvious seasonality. A maximum Kuroshio intrusion occurs in winter when Trichodesmium is scarce in its water, and vice versa for summer (Hu et al. 2000). The intrusion of the Kuroshio in fact might not bring a large amount of Trichodesmium into the SCS. This might be one of the reasons why the sedimentation of Trichodesmium was not high in the present study. Grazing (O'Neil \& Roman 1992) and/or microbial lysis/lyses in the euphotic layer are probably the main destiny of Trichodesmium biomass.

Acknowledgements. We thank Drs. Y. Chung and G. W. Hung for sharing the samples of the sediment trap. The National Center of Ocean Research financially supported the trap deployments. We appreciate the assistance and the cooperation of the captain and crews of the RV 'Ocean Researcher I'. This study was supported in part by the National Science Council, Taiwan, Republic of China through grants NSC 892611-M110-021-OP1, NSC 90-2611-M110-005-OP1 and NSC 91-2611-M110-011. 


\section{LITERATURE CITED}

Anadon R, Alvarez-Marques F, Fernandez E, Varela M, Zapata M, Gasol JM, Vaque D (2002) Vertical biogenic particle flux during Austral summer in the Antarctic Peninsula area. Deep-Sea Res II 49:883-901

Bell PRF, Elmetri I, Uwins P (1999) Nitrogen fixation by Trichodesmium spp. in the central and northern Great Barrier Reef Lagoon: relative importance of the fixed nitrogen load. Mar Ecol Prog Ser 186:119-126

Borgne RL, Barber RT, Delcroix T, Inoue HY, Mackey DJ, Rodier M (2002) Pacific warm pool and divergence: temporal and zonal variations on the equator and their effects on the biological pump. Deep-Sea Res II 49:2471-2512

Bronk DA (2002) Dynamics of DON. In: Hansell DA, Carlson CA (eds) Biogeochemistry of marine dissolved organic matter. Academic Press, San Diego, CA, p 153-247

Capone DG, Zehr J, Paerl H, Bergman B, Carpenter EJ (1997) Trichodesmium: a globally significant marine cyanobacterium. Science 276:1221-1229

Capone DG, Subramaniam A, Montoya JP, Voss M, Humborg C, Johansen AM, Siefert RL, Carpenter EJ (1998) An extensive bloom of the $\mathrm{N}_{2}$-fixing cyanobacterium Trichodesmium erythraeum in the central Arabian Sea. Mar Ecol Prog Ser 172:281-292

Carpenter EJ (1983a) Nitrogen fixation by marine Oscillatoria (Trichodesmium) in the world's oceans. In: Carpenter EJ, Capone DG (eds) Nitrogen in the marine environment. Academic Press, New York, p 65-103.3

Carpenter EJ (1983b) Physiology and ecology of marine planktonic Oscillatoria (Trichodesmium). Mar Biol Lett 4:69-85

Carpenter EJ, McCarthy JJ (1975) Nitrogen fixation and uptake of combined nitrogenous nutrients by Oscillatoria (Trichodesmium) thiebautii in the western Sargasso Sea. Limnol Oceanogr 20:389-401

Carpenter EJ, Price CC (1976) Marine Oscilllatoria (Trichodesmium): explanation for aerobic nitrogen fixation without heterocysts. Science 191:1278-1280

Carpenter EJ, Price CC (1977) Nitrogen fixation, distribution, and production of Oscillatoria (Trichodesmium) spp. in the Western Sargasso and Caribbean Seas. Limnol Oceanogr 22:60-72

Carpenter EJ, Romans K (1991) Major role of the cyanobacterium Trichodesmium in nutrient cycling in the North Atlantic Ocean. Science 254:1354-1358

Carpenter EJ, Montoya JP, Burns J, Mulholland MR, Subramaniam A, Capone DG (1999) Extensive bloom of a $\mathrm{N}_{2^{-}}$ fixing diatom/cyanobacterial association in the tropical Atlantic Ocean. Mar Ecol Prog Ser 185:273-283

Chang J, Chiang KP, Gong GC (2000) Seasonal variation and cross-shelf distribution of nitrogen-fixing cyanobacterium, Trichodesmium, in southern East China Sea. Cont Shelf Res 20:479-492

Chen CTA (1996) The Kuroshio intermediate water is the major source of nutrients on the East China Sea continental shelf. Oceanol Acta 19:523-527

Chen CTA, Huang MH (1996) A mid-depth front separating the South China Sea water and the Philippine Sea water. J Oceanogr 52:17-25

Devassy VP, Bhattathiri PMA, Qasim SZ (1978) Trichodesmium phenomenon. Indian J Mar Sci 7:168-186

Draper NR, Smith H (1981) Applied regression analysis. John Wiley \& Sons, New York

Dugdale RC, Menzel DW, Ryther JH (1961) Nitrogen fixation in the Sargasso Sea. Deep-Sea Res 7:297-300

Dugdale RC, Goering JJ, Ryther JH (1964) High nitrogen fixation rates in the Sargasso Sea and Arabian Sea. Limnol
Oceanogr 9:507-510

Falkowski PG (1997) Evolution of the nitrogen cycle and its influence on the biological sequestration of $\mathrm{CO}_{2}$ in the ocean. Nature 387:272-275

Fang G, Fang W, Fang Y, Wang K (1998) A survey of studies on the South China Sea upper ocean circulation. Acta Oceanogr Taiwan 37:1-16

Gao Y, Kaufman YJ, Tanre D, Kolber D, Falkowski PG (2001) Seasonal distributions of aeolian iron fluxes to the global ocean. Geophys Res Lett 28(1):29-32

Garside C (1982) A chemiluminescent technique for the determination of nanomolar concentrations of nitrate and nitrite in seawater. Mar Chem 11:159-167

Gong GC, Liu KK, Liu CT, Pai SC (1992) Chemical hydrography of the South China Sea and a comparison with the West Philippine Sea. Terres Atmos Ocean Sci 3:587-602

Hsu MK, Liu AK (1999) Nonlinear internal waves in the South China Sea. Proc 9th Int Offshore Polar Eng Conf, Brest, France, p 175-180

Hu J, Kawamura H, Hong H, Qi Y (2000) A review on the currents in the South China Sea: seasonal circulation, South China Sea Warm Current and Kuroshio intrusion. J Oceanogr 56:607-624

Hung JJ, Chen CH, Gong GC, Sheu DD, Shiah FK (2003) Distributions, stoichiometric patterns and cross-shelf exports of dissolved organic matter in the East China Sea. Deep-Sea Res II 50:1127-1145

Jackson GA, Williams PM (1985) Importance of dissolved organic nitrogen and phosphorus to biological nutrient cycling. Deep-Sea Res I 32:223-235

Karl D, Letelier R, Tupas L, Dore J, Christian J, Hebel D (1997) The role of nitrogen fixation in biogeochemical cycling in the subtropical North Pacific Ocean. Nature 386:533-538

Kromkamp J, Walsby AE (1992) Buoyancy regulation and vertical migration of Trichodesmium: a computer-model prediction. In: Carpenter EJ, Capone DG, Rueter JG (eds) Marine pelagic cyanobacteria: Trichodesmium and other diazotrophs. Kluwer Academic, Dordrecht, p 239-248

Letelier RM, Karl DM (1998) Trichodesmium spp. physiology and nutrient fluxes in the North Pacific subtropical gyre. Aquat Microb Ecol 15:265-276

Liu CL (2001) Distribution of dissolved and particulate organic carbon, nitrogen and phosphorus in the South China Sea and the Taiwan Strait. MSc thesis, National Sun Yat-sen University, Kaohsiung, Taiwan

Liu KK, Chao SY, Shaw PT, Gong GC, Chen CC, Tang TY (2002) Monsoon-forced chlorophyll distribution and primary production in the South China Sea: observations and a numerical study. Deep-Sea Res I 49:1387-1412

Marumo R, Asaoka O (1974) Distribution of pelagic bluegreen algae in the North Pacific Ocean. J Oceanogr Soc Jpn 30:77-85

Marumo R, Nagasawa S (1976) Seasonal variation of the standing crop of a pelagic blue-green alga, Trichodesmium in the Kuroshio water. Bull Plankton Soc Jpn 23:19-25

Mulholland MR, Capone DG (2000) The nitrogen physiology of marine $\mathrm{N}_{2}$-fixing cyanobacteria Trichodesmium spp. Trends Plant Sci 5:148-153

Ohki K, Rueter JG, Fujita Y (1986) Cultures of the pelagic cyanophytes Trichodesmium erythraeum and T. thiebautii in synthetic medium. Mar Biol 91:9-13

O'Neil JM, Roman MR (1992) Grazers and associated organisms of Trichodesmium. In: Carpenter EJ, Capone DG, Rueter JG (eds) Marine pelagic cyanobacteria: Trichodesmium and other diazotrophs. Kluwer Academic, Dordrecht, p 61-71 
Rueter JG, Ohki K, Fujita Y (1990) The effect of iron nutrition on photosynthesis and nitrogen fixation in cultures of Trichodesmium (Cyanophyceae). J Phycol 26:30-35

Rueter JG, Hutchins DA, Smith RW, Unsworth NL (1992) Iron nutrition of Trichodesmium. In: Carpenter EJ, Capone DG, Rueter JG (eds) Marine pelagic cyanobacteria: Trichodesmium and other diazotrophs. Kluwer Academic, Dordrecht, p 289-306

Saino T, Hattori A (1978) Diel variation in nitrogen fixation by a marine blue-green alga, Trichodesmium thiebautii. Deep-Sea Res 25:1259-1263

Saino T, Hattori A (1980) Nitrogen fixation by Trichodesmium and its significance in nitrogen cycling in the Kuroshio area and adjacent waters. In: Takenouti AY (ed) The Kuroshio IV. Saikon Publishing, Tokyo, p 697-709

Sanudo-Wilhelmy SA, Kustka AB, Gobler CJ, Hutchins DA and 6 others (2001) Phosphorus limitation of nitrogen fixation by Trichodesmium in the central Atlantic Ocean. Nature 411:66-69

Shaw P, Chao S (1994) Surface circulation in the South China Sea. Deep-Sea Res I 41:1663-1683

Tang TY, Liang WD, Yang YJ, Chuang WS (2002) Kuroshio intrusion in the Luzon Strait. Abstract from Workshop for 2002 Oceanographic Research Program, 23-23 December.

Editorial responsibility: Otto Kinne (Editor),

Oldendorf/Luhe, Germany
Taitung, Taiwan, p 1-2

Thomson-Bulldis A, Karl D (1998) Application of a novel method for phosphorus determinations in the oligotrophic North Pacific Ocean. Limnol Oceanogr 43: 1565-1577

Vidal M, Duarte CM, Agusti S (1999) Dissolved organic nitrogen and phosphorus pools and fluxes in the central Atlantic Ocean. Limnol Oceanogr 44:105-115

Vitousek PM, Howarth RW (1991) Nitrogen limitation on land and in the sea-how can it occur? Biogeochemistry 13: 87-115

Walsby AE (1978) The properties and buoyancy-providing role of gas vacuoles in Trichodesmium Ehrenberg. $\mathrm{Br}$ Phycol J 13:103-116

Wille N (1904) Die Schizophyceen der plankton expedition. Ergeb Humbolt-Stift 4:1-88

Wu J, Chung SW, Wen LS, Liu KK, Chen YL, Chen HY, Karl DM (2003) Dissolved inorganic phosphorus, dissolved iron, and Trichodesmium in the oligotrophic South China Sea. Global Biogeochem Cycles 17(1):1008

Zehr JP, Waterbury JB, Turner PJ, Montoya JP, Omoregle E, Steward GF, Hansen A, Karl DM (2001) Unicellular cyanobacteria fix $\mathrm{N}_{2}$ in the subtropical North Pacific Ocean. Nature 412:635-638

Submitted: January 29, 2003; Accepted: June 14, 2003 Proofs received from author(s): August 26, 2003 